\section{Anesthesia for Partial Bilateral Salpin- gectomy in a Patient with Idiopathic Hypertrophic Cardiomyopathy. Case Report and Review of the Literature}

\author{
Ana Sofia Del Castillo Sardi, M.D., Gustavo Ramboa, M.D., \\ Norma Sardi, M.D.
}

\section{INTRODUCTION}

Hypertrophic cardiomyopathy $(\mathrm{HC})$ is a genetic cardiac disease or dysfunction, autosomal dominant, caused by mutations in at least one out of 12 sarcomeric and non-sarcomeric genes, and it is recognized as one of the causes of sudden cardiac death in young patients ${ }^{1}$. It has a prevalence of $0.2 \%$ $(1: 500)$ in the general adult population ${ }^{2}$, and it is logic to think that patients with this disorder will undergo preoperative and anesthetic care at least once during their lives. For this reason, anesthesiologists should anticipate the hemodynamic changes and cardiovascular instability those patients are subject to.

The pathophysiology of hypertrophic cardiomyopathy is complex and, even though studies indicate that absolute maternal mortality in gravidas and puerperae with this disease is low ${ }^{3}$, we should take into consideration all hemodynamic changes inherent to pregnancy when seeing those patients.

We present the case of a patient with $\mathrm{HC}$ who underwent bilateral partial salpingectomy under combined epidural-spinal block, after a non-complicated vaginal delivery.

\section{CASE REPORT}

A 25-year old female on her second pregnancy, with a diagnosis of hypertrophic cardiomyopathy for four years. During the interview, the patient referred occasional palpitations during the pregnancy, being treated with $100 \mathrm{mg}$ of atenolol a day. She had a history of a vaginal delivery two years before without complications. The patient also had a history of mild asthma controlled with the occasional use of inhalational corticosteroids.

On physical exam, the patient was $1.63 \mathrm{~m}$ high and weighed $60 \mathrm{~kg}$. Besides marked IV/VI systolic and plurifocal heart murmur, the patient also had severe scoliosis with palpable intervertebral spaces.

Laboratorial exams showed CBC, creatinine, and electrolytes within normal limits; echocardiogram with predominantly septal hypertrophic cardiomyopathy and ejection fraction of $0.76 \%$.

The patient went on urgent labor; she was monitored during the procedure, giving birth to a live female fetus with Apgar $9 / 9$, without maternal or fetal hemodynamic complications.
She was admitted to Obstetric Pathology and scheduled for a partial bilateral salpingectomy. During the interview, the patient was calm and cooperative, but she did not want to undergo general anesthesia for the procedure. The advantages and disadvantages of regional blocks as well as the possibility of undergoing general anesthesia were explained to her, but she was vehemently against general anesthesia, saying that she would cancel the procedure if we insisted on this form of anesthesia.

After an 8-hour fasting period, the patient was pretreated with $10 \mathrm{mg}$ of metochlopramide and $50 \mathrm{mg}$ of ranitidine IV 30 minutes before the procedure. Monitoring consisted on blood pressure, pulse oximetry, and electrocardiography. With the patient in the sitting position, the epidural space was punctured at the L4-L5 level with a 17G Touhy needle. Using a 25G x 43/4" (120 mm) Sprotte pencil-tip needle, $7.5 \mathrm{mg}$ of levobupivacaine and $25 \mu \mathrm{g}$ of fentanyl were injected in the subarachnoid space followed by the insertion of an epidural catheter. The patient was placed on the supine position to determine the sensorial level, which was at T5. The surgical procedure lasted 20 minutes, and blood pressure and heart rate were $10 \%$ lower than baseline levels without immediate hemodynamic or surgical complications; the patient did not require vasopressor support. Maternal hydration during the procedure reached $100 \mathrm{~mL}$ with a diuresis of $50 \mathrm{ml}$.

The patient was transferred to the post-anesthetic care unit; she was calm, awake, cooperative, and remained hemodynamically stable. Afterwards, she was transferred to the semi-intensive care unit at the obstetric pathology room, being discharged after three days and referred to Cardiology follow-up.

\section{DISCUSSION}

Hypertrophic cardiomyopathy, also known as asymmetrical septal hypertrophy, is an autosomal disorder with structural changes in contractile cardiac cells, left ventricular hypertrophy, especially of the septum, and changes in the conduction system ${ }^{4}$.

Hypertrophic cardiomyopathy is a unique cardiovascular disease, since it can present at any time during one's life, from infancy to 90 years of age ${ }^{5}$.

Cardiac cells both in the septum and free left ventricular wall show an increase in transversal diameter, strange forms, and a disorganized architectural pattern ${ }^{6}$. Primary malformations of the mitral valve responsible for the left ventricular outlet obstruction are present in at least two thirds of the patients ${ }^{7}$.

The diagnosis is usually established by a two-dimensional echocardiogram that shows left ventricular hypertrophy (wall thickness of at least $15 \mathrm{~mm}$ ), typically asymmetrical, associated with a non-dilated chamber in the absence of any other cardiac or systemic disorder ${ }^{8}$. The 12-lead ECG is abnormal in $75 \%$ to $90 \%$ of the cases of hypertrophic cardiomyopathy, showing a wide range of abnormal patterns, but none of them is pathognomonic or highly specific of the disease. Among 
them, changes in the ST segment and inversion of the T wave (consistent of left ventricular hypertrophy), and abnormal $Q$ waves with a reduction or absence of $R$ waves in left precordial leads (increased left atrium) are seen ${ }^{9}$.

Pathophysiologically, three main factors are responsible for the left outlet obstruction: 1) increased contractile strength; 2) reduction of left ventricular end-diastolic volume, secondary to an increase in heart rate or decrease in venous return; and 3) reduction in systemic vascular resistance. Those changes along with ventricular hypertrophy increase oxygen consumption with the consequent risk of subendocardial ischemia and changes in the conduction system with the possible development of arrhythmias ${ }^{10}$.

As a rule, hypertrophic cardiomyopathy has a variable course and patients can remain stable for long periods of time, and a large proportion of those patients lead a normal life ${ }^{5}$. Usually, symptomatic patients tend to develop progressive cardiac failure with dyspnea, fatigue, and precordial pain; occasionally they reach terminal stages with atrial fibrillation and sudden death ${ }^{9}$.

Treatment of this disorder can be clinical or surgical. Negative inotropic drugs, such as $\beta$-blockers and verapamil, have been widely used to control symptoms since they reduce the degree of the left ventricular outlet obstruction and also have antiarrhythmic and anti-anginous properties ${ }^{4}$. Type IA antiarrhythmic agents, such as disopyramide, can be used in patients that are refractory to the aforementioned drugs $^{11}$. Surgical treatment includes ventricular septal myomectomy (Morrow procedure), the first therapeutic option in obstructive hypertrophic cardiomyopathy (resting gradient after physiological challenge $\geq 50 \mathrm{mmHg}$ ) and severe symptoms refractory to clinical treatment. Those patients represent only about $5 \%$ of the total number of patients with hypertrophic cardiomyopathy ${ }^{12}$.

Currently, little information on the anesthetic risks of patients with hypertrophic cardiomyopathy exists, probably because few patients with a confirmed diagnosis need an anesthesiologist ${ }^{13}$. As a rule, we should consider maneuvers to preserve systolic volume as well as reducing contractility and sympathetic discharge (for example, with $\beta$-blockers), increasing filling and afterload pressures (with hydration and $\alpha-1$ adrenergic agonists). Invasive blood pressure monitoring can be useful before anesthetic induction to recognize episodes of hypotension as well as transesophageal Doppler echocardiogram, which allows observing the morphology of the left ventricular outlet tract and mitral valve.

Tranquilizers (benzodiazepines) are indicated to block sympathetic activation; the administration of anticholinergic agents, such as atropine or glycopirrolate, should be avoided since they are potentially tachycardic. Slow drug titration should be used during induction to avoid sudden episodes of hypotension, and the patient should only be intubated after enough depression of the sympathetic response is achieved. When neuromuscular blockers are used, the release of histamine, vagolytic and muscarinic activities, and prevention of reuptake of catecholamines should be considered, and vecuronium is well tolerated.

Since myocardial depression is, as a rule, a desired effect during anesthesia maintenance, volatile agents are indicated in patients with $\mathrm{HC}$, always monitoring for possible sudden hemodynamic changes. Sevoflurane is the best agent, since it causes moderate myocardial depression and more discrete changes in systemic vascular resistance, blood pressure, and heart rate.

Patients should be ventilated with low tidal volumes and high respiratory rates to maintain adequate minute ventilation. Treatment of acute hypotension in the operating room requires fast volume infusion and the administration of adrenergic -1 agonists (phenylephrine, for example). Beta-adrenérgicos agonists, such as dopamine, dobutamine or ephedrine, are not adequate options because they increase cardiac inotropism and chronotropism, promoting left ventricular outlet obstruction and increasing oxygen consumption.

Since those patients are at risk for the development of arrhythmias during induction, anesthesia maintenance is very important to preserve the sinus rhythm; if the patient develops atrial fibrillation in the operating room, it should be treated with direct cardioversion instead of pharmacologically.

Pregnant patients with $\mathrm{HC}$ have special considerations due to the unique cardiovascular changes inherent to pregnancy. In later stages, aortocaval compression or higher blood loss during labor can reduce preload considerably. On the other hand, pain and labor stress can generate a sympathetic stimulation, increasing the heart rate and contractility, contributing for hemodynamic deterioration. Recent studies have reported a very low maternal mortality rate in gravidas with $\mathrm{HC}$, and it usually affects women with high risk factors ${ }^{3}$. Evidence does not indicate that regional blocks increase the risk of women with $\mathrm{HC}$ during vaginal deliveries. Both general anesthesia and regional blocks were successfully used in cesarean sections of gravidas with $\mathrm{HC}$ without complications ${ }^{14}$. The successful administration of combined and continuous epidural-spinal blocks has been documented in case reports ${ }^{10,15}$.

In our patient, the combined regional block was used since she refused to undergo general anesthesia; therefore, lower amounts of local anesthetic and opioids were used avoiding sudden hemodynamic changes and favoring a speedy recovery.

Communication between the Cardiology and Obstetric teams was maintained during the whole time. We concluded that simple measures such as anesthetic planning, monitoring, and cooperation of all those involved were paramount for the anesthetic success in our patient. 


\section{REFERÊNCIAS - REFERENCES}

1. Maron BJ. Hypertrophic cardiomyopathy: a systemic review. JAMA 2002;287:1308-1320.

2. Maron BJ. Hypertrophic cardiomyopathy: an important global disease. Am J Med 2004;116:63-65.

3. Autore $\mathrm{C}$, Conte MR, Piccininno M et al. Risk associated with pregnancy in hypertrophic cardiomyopathy. J Am Coll Cardiol 2002;40:1864-1869.

4. Jackson JM, Thomas SJ. Valvular heart disease. In: Kaplan JA. Cardiac anesthesia, 3rd Ed. Phidadelfia: WB Saunders, 1999;644-650.

5. Maron BJ, Casey SA, Poliac LC et al. Clinical course of hypertrofic cardiomyopathy in a regional United States cohorte. JAMA 1999;281:650-655

6. Shirani J, Pick R, Roberts WC et al. Morphology and significance of the left ventricular collagen network in young patients with hipertrophic cardiomyopathy and sudden cardiac death. J Am Coll Cardiol 2000;35:36-44.

7. Klues HG, Maron BJ, Dollar AL et al. Diversity of structural mitral valve alterations in hypertrofic cardiomyopathy. Circulation 1992; 85:1651-1660.

8. Klues HG, Schiffers A, Maron BJ. Phenotypic spectrum and patterns of left ventricular hypertrophy in hypertrophic cardiomyopathy: morphologic observations and significance as assessed by two-dimensional echocardiography in 600 patients. J Am Coll Cardiol 1995;26:1699-1708.

9. Poliac LC, Barron ME, Maron BJ - Hypertrofic cardiomopathy. Anesthesiology 2006;104:183-192.

10. Stocche RM, García LV, Klamt JG. Anestesia para cesaria en paciente portadora de cardiomiopatía hipertrófica familiar. Relato de Caso. Rev Bras Anestesiol 2007;57:382-385.

11. Sherrid MV, Barac I, McKenna WJ et al. Multicenter study of the efficacy and safety of disopyramide in obstructive hypertrofic cardiomyopathy. J Am Coll Cardiol 2005;45:1251-1258.

12. Maron BJ, Dearani JA, Ommen SR et al. The case for surgery in obstructive hypertrofic cardiomyopathy. J Am Coll Cardiol 2004;44:2044-2053.

13. Haering JM, Comunale ME, Parker RA et al. Cardiac risk of noncardiac surgery in patients with asymmetric septal hypertrophy. Anesthesiology 1996;85:254-259.

14. Thaman R, Varnava A, Hamid MS et al. Pregnancy related complications in women with hypertrophic cardiomyopathy. Heart 2003;89:752-756.

15. Autore $\mathrm{C}$, Brauneis $\mathrm{S}$, Apponi $\mathrm{F}$ et al. Epidural anesthesia for cesarean section in patients with hypertrophic cardiomyopathy: a report of three cases. Anesthesiology 1999;90:1205-1207.

\section{RESUMEN}

Sardi ASC, Ramboa G, Sardi N - Anestesia para Salpingectomía Parcial Bilateral en Paciente con Miocardiopatía Hipertrófica Idiopática. Relato de Un Caso y Revisión del Literatura *

JUSTIFICATIVA Y OBJETIVOS: La cardiomiopatía hipertrófica es enfermedad cardíaca rara, con transmisión autosómica dominante que se caracteriza por hipertrofia del septum ventricular y anormalidades de la válvula mitral.

RELATO DEL CASO: Paciente segundigesta, 25 años con diagnóstico de cardiomiopatía hipertrófica hace 4 años e antecedente de asma bronquial leve intermitente controlada con inhalaciones esporádicas de corticoesteroides. Presentaba soplo holosistólico IVIVI plurifocal e importante escoliosis, con los espacios intervertebrales palpables. Refirió palpitaciones esporádicas durante todo el embarazo y se encontraba medicada con $100 \mathrm{mg}$ de atenolol diarios. Presentaba hemograma, creatinina y electrolitos dentro de los límites normales, ecocardiograma que reportaba cardiomiopatía hipertrófica de predominio septal con fracción de eyección sistólica del $76 \%$. La paciente entró en labor de parto de urgencia, obteniéndose producto femenino vivo, APGAR 9/9, sin complicaciones hemodinámicas maternas ni fetales. Se programa para la realización de salpingectomía parcial bilateral. Se entrevista a la paciente, la cual nos refirió que se rehusaba a recibir anestesia general para el procedimiento. La técnica anestésica elegida fue la regional combinada. El procedimiento quirúrgico duró 20 minutos, y los cambios de presión arterial y frecuencia cardíaca fue menos del $10 \%$ que el de los valores iniciales, sin complicaciones hemodinámicas ni quirúrgicas inmediatas.

CONCLUSIONES: La mortalidad absoluta materna con cardiomiopatia hipertrófica $(\mathrm{CH})$ es muy baja y suele estar confinada a mujeres con factores de alto riesgo. No hay evidencia que la anestesia regional aumenta el riesgo en mujeres con $\mathrm{CH}$ cuando se utiliza para el parto vaginal. Tanto la anestesia general como regional han sido utilizado con éxito y sin complicaciones en cesáreas de parturientas con $\mathrm{CH}$. 